\title{
Factors Influencing Clothing Interest and Purchase Intention: A Study of Generation Y Consumers in Malaysia
}

\author{
Cham, T.H. ${ }^{{ }^{*}}$, Ng, C.K.Y. ${ }^{2}$, Lim, Y.M. ${ }^{1}$ and Cheng, B.L. ${ }^{3}$ \\ ${ }^{1}$ Faculty of Accountancy and Management, Universiti Tunku Abdul Rahman, Malaysia. \\ ${ }^{2}$ Division of Corporate Communication and Public Relations, Universiti Tunku Abdul Rahman, Malaysia. \\ ${ }^{3}$ Department of Marketing, Sunway University, Malaysia.
}

\begin{abstract}
The purpose of this study is to examine the factors influencing clothing interest among Generation Y consumers in Malaysia. Brand image, word of mouth, self-concept, perceived quality, and need for uniqueness were hypothesized to be related with clothing interest, which in turn, was deemed to be related with purchase intention. The interaction effect of price consciousness on the relationship between clothing interest and purchase intention was also examined in this study. Self-administered questionnaires were used to collect data from a total of 300 respondents from Malaysia to test the hypothesized relationships. Results showed that need for uniqueness, self-concept, brand image, word of mouth, and perceived quality are significant predictors of clothing interest among the Generation Y consumers in Malaysia and price consciousness moderated the relationship between their clothing interests and purchase intention. The practical implications of the research findings were discussed.
\end{abstract}

Keywords: Brand Image, Clothing Interest, Generation Y, Need for Uniqueness, Perceived Quality, Price Consciousness, Purchase Intention, Self-concept, Word of mouth.

*Corresponding Author:

Name: Cham Tat Huei

Address: Universiti Tunku Abdul Rahman (UTAR), Bandar Sungai Long, 43000 Kajang, Selangor, Malaysia.

Email: chamth@utar.edu.my/ jaysoncham@gmail.com

Phone: +6012-5825266 


\section{Introduction}

Clothing is an essential item in every individual's life as it is considered the second skin of the body. According to Maslow's hierarchy of needs (Maslow 1987), clothes fall into the category of physiological needs and fulfill the fundamental need of protection for all individuals. However, clothing has taken on an additional function in this modern world. Not only it serves as a basic human need, it also symbolizes an individual. People use clothes to express and differentiate themselves from others. Clothes have become a communication medium used to convey who the person is. They are visual items representing a person's identity and personality-gender, age, race, occupation, social and financial status, fashion tastes, color preferences, time orientation, liking, pride, attitudes, degree of maturity, selfconfidence, and self-esteem (Rosenfeld and Plax 1977). There are other significant roles played by clothing. Clothes have also shown to be associated with the identity of the country, religious beliefs, political events, and historical eras.

Companies \& Markets (2015), one of the world's largest databases for market research, reported that the global apparel industry continuously shows promising growth with approximately 1.2 trillion dollars of sales. This industry is supported by about 60 to 75 million workforce throughout the world in the footwear, textile, sportswear, and clothing sectors. It was further reported that China, Bangladesh, and India are ranked as the top garment producing countries while European countries, United States, and Japan are the main garment importing countries. Moreover, South East Asia countries like Malaysia, Singapore, Indonesia, and Thailand benefited from this growing industry whereby more and more clothing retail outlets from various international brands (e.g. H\&M, Uniqlo, Topshop, Victoria Secret, and GAP) have shown their significant presence in these countries. The internationalization of clothing industry has created a huge impact on consumers' interest and buying behavior with respect to their clothing (Subhani, Hasan, and Osman 2011).

Among consumers of different age groups, it has been found that Generation $\mathrm{Y}$ consumers play an important role in the consumption of fashion products (Tee, Gharleghi, and Chan 2013). People of Generation Y were born between 1977 and 1994 (Paul 2001) and they were between 21 and 38 years old as of 2015. They generally display a higher degree of acceptance and tolerance of differences in cultures, lifestyles, and behaviors (Promar International 2001; Tee et al. 2013). Tee et al. (2013) further argued that Generation Y consumers have more disposable income to spend, and this makes them a target market of 
many uprising international brands such as Uniqlo, Levis, Cotton On, H\&M, Monki, Topshop, GAP, and Fred \& Perry, to name a few. This fact is well supported by the study by Khan et al. (2016) whereby most Generation Y Malaysian consumers spent their time in the shopping mall during weekends, public holidays, and even during weekdays (Euro monitor International 2013). Furthermore, Generation Y consumers have established themselves in the urban areas. They are young working adults graduated from colleges and universities located in the metropolitan areas. They have acquainted with the urban lifestyle and become the right target market for many fashion retailers (Kim, Knight, and Pelton 2009).

Generation Y consumers may be a lucrative market for clothing retailers, especially the branded ones, but research studies on their interest and buying intention of clothing are scant. Kumar, Kim, and Pelton (2009) have suggested that more studies are needed to determine the significant factors in relation to clothing interest and purchase intention. Although Kumar et al.'s (2009) study found that the need for uniqueness and self-concept have a significant positive relationship with clothing interest, studies on clothing interest that considers the impact from the marketing aspects such as brand image and word of mouth are still scarce and have little empirical evidence. Furthermore, Tsiotsou (2006) has argued that the quality of clothing plays an important role in influencing individual's clothing interest. Yet this factor has not been given much needed attention. Therefore, this research aims to examine whether these factors - need for uniqueness, self-concept, brand image, word of mouth, and perceived quality — significantly influence clothing interest among the consumers of Generation Y in Malaysia.

This research study also aims to investigate the relationships among clothing interest, price conscious, and purchase intention of clothing. Studies have found a positive relationship between consumers' interest of clothing and their intention to purchase (Kumar et al. 2009; Vikkraman and Sumathi 2012). Other studies found that the level of price consciousness among the consumers will influence their purchase decision (Gauzente and Roy 2012; Jayasingh and Eze 2012). These research findings indicate a possible interaction effect of price consciousness on the relationship between clothing interest and purchase intention. Consumers who are highly conscious about price may not purchase the clothes that they are interested in buying if the price is too expensive. In other words, price consciousness may moderate the relationship between clothing interest and purchase intention. However, a review of the literature indicates that studies examining such a moderated relationship are 
virtually none. As a result, there is a need to address this research gap in pertaining to purchase intention of clothing.

Based on the research deficiency identified above, this study attempts to achieve the following objectives:

1) To examine whether need for uniqueness, self-concept, brand image, word of mouth, and perceived quality are significant predictors of clothing interest among the Generation Y consumers in Malaysia.

2) To determine the moderating effect of price consciousness on the relationship between their clothing interest and purchase intention.

The following section presents a review on the factors influencing clothing interest and the development of hypotheses.

\section{Literature Review and Hypotheses Development}

\section{Factors that influence Clothing Interest}

Clothing interest is defined as an individual's "attitude and beliefs about clothing, the knowledge of and attention paid to their clothing, and the concern and curiosity a person has about his/her clothing and that of others" (Gurel 1974, 12). Clothing interest among individuals can be shown by their practices in terms of the degree to which they use clothing in an experimental manner; the amount of energy, time, and money that they willing to sacrifice on clothing, and their awareness of new fashion (Gurel 1974; Kaiser 1997; Lukavsky, Butler, and Harden 1995). In other words, how much an individual is interested in clothing depends upon his/her beliefs, attitudes, knowledge, attention, and curiosity about clothing. Furthermore, clothing serves as a communication tool to project an individual's image that is socially desirable (Kamenidou, Mylonakis, and Nikolouli 2007; Kumar et al. 2009). Consumers' clothing interest is of great interest to the producers and retailers in the fashion industry. These industry players are eager to know what would create interest among the consumers in buying certain type of clothing (Zeb, Rashid, and Javeed 2011). 


\section{Need for Uniqueness and Clothing Interest}

The word "unique" means "the only one of a particular type" (Dictionary.com, 2014). Generally, individuals are motivated to maintain a sense of uniqueness within selves and want to project that unique self onto others (Snyder and Fromkin 1980). Those who have a higher need for uniqueness tend to have a higher desire of dissimilarity from others (Lynn and Harris 1997). Need for uniqueness has become a universal personality for the youth group of consumers as they have higher tendency in craving for uniqueness at some point in their lives (Bao and Shao 2002). It was further argued that uniqueness of the products (i.e. clothing) can create the "cool" and "wow" effect for the youth group of consumers.

Past studies have reported that those consumers with a high need for uniqueness tend to have a high interest in new products and brands; and they constantly look out for selfdifferentiating and non-out-of-date goods (Tian, Bearden, and Hunter 2001; Tian and Mckenzie 2001). Consumers who want to be different from others almost always use clothing products to display their unique selves and social image (Kumar et al. 2009; Vikkraman and Sumathi 2012; Workman and Kidd 2000). In their study on 411 undergraduate respondents in India, Kumar et al. (2009) found that the higher the level of students' need for uniqueness, the higher the level of their interest on clothing. This finding is in consistent with the argument that clothing selection is a uniqueness-seeking behavior (Workman and Kidd, 2000). Accordingly, the following hypothesis was formed:

\section{H1: Need for uniqueness has a positive relationship with clothing interest.}

\section{Self-Concept and Clothing Interest}

Self-concept refers to the way in which respective individuals take charge of their own thinking, feelings, behaviors, attitudes, and actions in interpreting the environment that surrounds them (Farber 1983; Stryker 1987). According to Kumar et al. (2009), self-concept can be regarded as a feeling whereby an individual has the thought and sense of being different from others. In the consumer market, consumers often use certain products to represent their identity or personality although those products may not have much functional or tangible quality (Kumar et al. 2009). For example, they may use clothing of certain brands to project their desired selves among the people around them. Clothes could be a selfexpression tool (Phau and Lau 2001; Kumar et al. 2009). Kumar et al. (2009) further argued that consumers usually exhibit a high interest in their clothing especially when they are 
concerned with their self-concept and social identity. The relationship between an individual's self-concept and their clothing interest has also been supported in other studies such as Banister and Hogg (2004), Bye and McKinney (2007), Piacentini and Mailer (2004), and Tuncay and Otnes (2008). Therefore, it was then hypothesized that:

H2: Self-concept has a positive relationship with clothing interest.

\section{Brand Image and Clothing Interest}

Brand image is defined as a set of perceptions about a product that is reflected by the brand association in the consumer's memory (Keller, 1993). A product's brand plays an important role in marketing. It serves as a source of information to identify with the product in relation to its unique features (Aaker, 2009). Brand image creates values to consumers in a variety of ways. It helps consumers to process information about the product, to differentiate one product from the other, to provide reasons to purchase the product, to generate positive feelings from the product, and to form a basis for extended use of the product (Rajagopal, 2006). Furthermore, brand image is able to create interest among customers towards a certain product or service offering. It has been reported that the more the brand is being recognized by the consumers, the higher their interests with a particular product or service (Koh and Fang 2012; Matthiesen and Phau 2010; Zeb et al. 2011). It is expected that the brand image of the clothing will have a positive relationship with consumers' clothing interest. Thus, it was formulated that:

H3: Brand image has a positive relationship with clothing interest.

\section{Word of Mouth and Clothing Interest}

Word of mouth (WOM) is defined as "any informal, person-to-person communication process between a perceived non-commercial communicator and a receiver regarding a service, an organization, a brand, or a product" (Harrison-Walker 2001, 63). It refers to some remarks made by an individual to another person about the good or bad experience with some products or services. In other words, WOM is a sort of personal communication about a brand, product, or service. Although the sender of information has no commercial intention (Arndt 1967), the transmitted information may influence another individual to purchase a certain product or service (Harrison-Walker 2001; Hung and Li 2007). WOM has been considered as one of the most powerful forces in business as it plays a very influential role in 
consumers' decision making (Martin and Jacob 2010). Companies like Nestle, Loreal, and Johnson \& Johnson have recognized the credibility of WOM as a highly informal persuasive tool in creating an engagement between the product and the customer (Nielsen 2009).

Literature has indicated that WOM can influence consumers' attitudes, behaviors, expectations, and perceptions (Trusov, Bucklin, and Pauwels 2009). WOM influences consumer buying behavior especially when it creates one's interest in certain products (Schindler and Bickart 2012). Various studies have found a significant positive relationship between WOM and clothing interest (Kiecker and Cowles 2002; McKinney et al. 2004). The study by McKinney et al. (2004) found that WOM generated from the reference group will have direct influence on the customers' behavior and interest in clothing selection in United States. Therefore, it was postulated that:

H4: Word of mouth has a positive relationship with clothing interest.

\section{Perceived Quality and Clothing Interest}

Perceived quality refers to the consumer's judgment on a product's overall performance or superiority rather than the actual quality of the product itself (Zeithaml 1988). Consumers judge the quality of the product based on some informational cues and then form a set of belief towards the product. The informational cues involve both extrinsic and intrinsic features in relation to the product (Zeithaml 1988). The extrinsic attributes include company's reputation, brand image, and pricing; while intrinsic attributes refer to the physical characteristics of the product such as product features, specifications, design, size, shape, materials used, and perceived durability.

In shopping for clothing, consumers usually create an interest on a particular type of clothing based on their sensory observation - the look, the touch, and the feel of the clothing products. The sensory observation would lead to a perception of how good or bad the clothes would be in terms of material, design, and workmanship (Tsiotsou 2006). Past studies reported that consumers' interest is created on how they perceive the quality of the products (Cook 2010; Ruban 2002). Studies from the apparel industry have found a significant relationship between customers' perceived quality and their clothing interest (Kawabata and Rabolt 1999; Lee and Burns 1993). Kawabata and Rabolt (1999) found that the quality aspect 
of the clothes will have an impact on the clothing interest among the American and Japanese customers. Hence, the following hypothesis was developed:

H5: Perceived quality has a positive relationship with clothing interest.

\section{The Moderating Effect of Price Consciousness on the Relationship between Clothing Interest and Purchase Intention}

Clothing is considered as one of the most common products used by individuals in addressing their psychodynamic and psychographic needs such as appearance, social status, and self-esteem (Stanforth 2009). The perceived ability of clothing in fulfilling these needs would arouse an individual's interest in clothing products. The individual would have the intention to buy clothing by devoting a large amount of effort and time to search for the right clothing products in order to fulfill the fore-mentioned types of needs (Kaiser 1997; Stanforth 2009). A number of studies did find a positive relationship between clothing interest and purchase intention (Kumar et al. 2009; Son, Jin, and George 2013; Vikkraman and Sumathi,2012). The study by Son et al. (2013) on 405 young consumers in India found that their interest in clothing has a significant impact on their apparel purchase intention. It was then hypothesized that:

H6: Clothing interest has a positive direct influence on purchase intention.

Price has been a common factor in influencing consumers' purchase decision-making and choice of products and services (Ryu and Han 2010). Consumers will evaluate the reasonableness or appropriateness of the price for a product or service and compare the prices charged by other competing businesses (Chen, Gupta, and Rom 1994; Gauzente and Roy 2012; Han and Ryu 2009; Jayasingh and Eze 2012; Kukar-Kinney, Walters, and MacKenzie 2007; Palazón and Delgado 2009; Watchravesringkan, Yan, and Yurchisin 2008). Customers may not purchase the product or services if the price is too expensive in comparison to that offered by other sellers. This phenomenon is known as price consciousness. Price consciousness refers to "a buyer's 'unwillingness' to pay a higher price for a product" (Lichtenstein, Ridgway, and Netemeyer 1993, 235). It has been argued that highly priceconscious consumers typically engage in a higher level of search in product prices to seek higher economic benefits (Alford and Biswas 2002; Kukar-Kinney et al. 2007). 
Various consumer behavior studies have found a moderating effect of price consciousness on the relationship between product interest and buying intention. For example, Choi and Kim's (2007) experimental study on 101 undergraduate students found that price consciousness moderated the relationship between "scratch and save" promotions and consumer's purchase intention. Moreover, Kukar-Kinney et al.'s (2007) study on 403 undergraduate students in US indicated that the level of price consciousness among the respondents has a moderating effect on the relationship between price-matching strategies by retailers with their purchase intention. Thus, consumers' price consciousness is a factor that influences their intention to purchase certain products. Accordingly, it was hypothesized that price consciousness will moderate the effect of consumers' clothing interest on their purchase intention.

H7: Price consciousness will moderate the relationship between clothing interest and purchase intention.

Figure 1 presents the research model developed for this study.

Display Figure 1 here.

\section{Research Methodology \\ Measurements and Questionnaire Development}

Survey questionnaire was used to collect data for the purpose of this study. The measurement scales used to operationalize the variables in this study were adapted from the existing literature. Need for uniqueness in this study was measured using five items scale by Tian et al. (2001), which indicate an individual's consumption of unique, rare clothes and brands. Self-concept measures individual's overall perception of his/her self based on the scale by Alfonso, Allison, Rader and Gorman (1996). The scale for brand image was adopted from Hsieh and Li (2008), which measures respondent's perception on whether a clothing brand possesses symbolic meanings, possesses practical functions, and will provide customers with positive experience. As for word of mouth, the construct was operationalized using the five items scale developed by O'Cass and Grace (2004). Word of mouth reflects the influence of family/friends on one's evaluation, decision making, understanding, attitude, and idea on clothing. Dodds, Kent, and Grewal's (1991) scale was adopted to measure perceived 
quality, which measures respondents' perceived durability, reliability, and overall quality of clothes purchased.

The scale measuring clothing interest was adopted from the study by Lumpkin (1985). The clothing interest was operationalized based on individual's favorite activity in clothing, enhancement of appearance though clothing, expenses on clothing, and their preferences on clothing. The six-item scale developed by Palazón and Delgado (2009) was used to measure price consciousness in this study. The items of price consciousness indicate the emphasis of pricing by the individual in purchasing clothes. As for clothing purchase intention, this study adopted the three-item scale developed by Kumar et al. (2009) measuring respondents' intention to purchase clothes. All of the items were measured in seven-point Likert scale, ranging from $1=$ strong disagree to $7=$ strongly agree.

Using a sample of 50 young adults, a pilot test was conducted before the actual data collection in order to ascertain the face validity of the measurement scales. The number of respondents for the pretest study was considered sufficient as suggested by Hair et al. (2010) and Sekaran (2005). The pretest of the questionnaire showed that all the measurement items were relevant and adequate in terms of coverage. Therefore, the face validity of the measurement scales used in this study was established.

\section{Sampling Method}

The target respondents of this study were consumers of Generation Y. Data were collected in four major shopping malls of the capital city (Kuala Lumpur) of Malaysia. The capital city is the largest city of Malaysia and has the highest number of shopping malls. Furthermore, it has attracted a large number of Generation Y consumers because of its availability of job opportunities and its strategic location for universities and colleges. A quota sampling was employed to collect data from a total of 300 Generation $\mathrm{Y}$ shoppers, evenly spread among the four shopping malls with 75 respondents each. Questionnaires were distributed using mall intercept method to the target respondents; and completed questionnaires were collected personally by the researcher on the spot during the survey period. Personal administered survey is considered an effective method to improve the response rate, to reduce any uncertainty and to create a co-operative atmosphere among the target respondents (Malhotra, 2004). 
The present study employed two screening criteria in selecting the respondents: (1) the individual must be born within the period of 1977 to 1994, and (2) the person has purchased at least one clothing product in the past one month. Out of the 300 distributed questionnaires, only 292 questionnaires were usable and eight were rejected due to incompleteness. The sample size of 292 for the present study is considered sufficient to represent a big population (Saunders, Lewis, and Thornhill, 2012) and for structural equation modeling analysis (Hair et al., 2010).

\section{Data Analysis \\ Sample Characteristics}

As seen in Table 1, 45.2\% of the respondents were male and $54.8 \%$ were female. About half of the respondents were Bachelor's degree holders (44.5\%) and working fulltime (59.9\%) with an earning between RM3,001 and RM6,000 (47.6\%). About two third of the respondents shopped for clothes between 1 to 6 times a month (76.4 percent).

\section{Display Table 1 here.}

\section{Convergent and Discriminant Validity of the Constructs}

Confirmatory factor analysis was used to examine measurement model fit and the convergent and discriminant validity of the data (Hair et al. 2010). Criteria used to evaluate measurement model fit include the following indices: (1) Goodness of Fit (GFI), (2) Comparative Fit Index (CFI), (3) Root Mean Square Error of Approximation (RMSEA), (4) Tucker-Lewis index (TLI), (5) Parsimony Normed Fit Index (PNFI), and (6) Normed Chisquare $\left(\chi^{2} / \mathrm{df}\right)$. A model is considered fit when GFI exceeds 0.90, CFI exceeds 0.90, RMSEA is less than 0.08 , TLI exceeds 0.90 , PNFI is more than 0.50 , and $\chi^{2} / \mathrm{df}$ is less than 3.0 (Hair et al., 2010). As for the present study, GFI was 0.908, CFI was 0.913, RMSEA was 0.049, TLI was 0.918, PNFI was 0.723 , and $\chi^{2} / \mathrm{df}=1.818\left(\chi^{2}=760.044 ; \mathrm{df}=418\right)$, indicating that the measurement model was fit.

Three conditions must be met in order to establish the convergent validity of the data (Hair et al. 2010). The three conditions are: (1) the factor loading each construct item must be at least $0.60,(2)$ the average variance extracted (AVE) of each construct should be larger than 
0.50 , and (3) the composite reliability of each construct should be greater than 0.70 . As seen in Table 2, the factor loadings of the construct items range from 0.627 to 0.933 , the AVE of each construct exceeds the cut-off point of 0.5 , and each construct has a composite reliability of more than 0.70 . Hence, the convergent validity of the data in the present study was established.

Display Table 2 here.

The discriminant validity of the data was assessed based on the guidelines suggested by Fornell and Larcker (1981). Discriminant validity is said to be established when the squared root of AVE for each of the constructs exceeds the variance shared between any two constructs. As shown in Table 3, all the shared variance between constructs (the off diagonal entries) are lesser than the squared root of AVE in the diagonal entries; hence, the discriminant validity was established. In sum, all constructs included in this study have demonstrated adequate reliability, convergent validity, and discriminant validity

\section{Display Table 3 here.}

The researchers also addressed the issue of common method variance (CMV) based on the suggestion by Malhotra et al. (2006). It is argued that CMV will generate a false internal consistency and correlation among the variables created by their common source (Chang et al., 2010; Malhotra et al., 2006). It is reported that common method bias may exist if the hypothesized model (with indicators for all the constructs to be modeled as a single factor) for CMV has a good model fit (Malhotra et al., 2006). As for the present study, the results showed that the hypothesized model based on the suggestion by Malhotra et al. (2006) is not fit; hence, common method bias is not a significant problem.

\section{Structural Model and Hypotheses Testing}

Structural equation modeling (SEM) was used to test the structural model of the present study. According to Hair et al. (2010), SEM is used by researchers to examine the overall fit of the model and to test the relative strengths of the individual causal paths. The structural model were shown to be fit with $\mathrm{GFI}=0.918, \mathrm{CFI}=0.912, \mathrm{RMSEA}=0.045$, TLI $=0.913, \mathrm{PNFI}=0.714$, and $\chi^{2} / \mathrm{df}=1.855$. The results of the causal paths were presented in 
Table 4. All the hypothesized relationships (H1 to H6) in this study were found to be significant. The results showed that the need for uniqueness, self-concept, brand image, word of mouth, and perceived quality have a significant influence on individual's clothing, which in turn, have a positive influence on the purchase intention.

\section{Display Table 4 here.}

The two-step procedure suggested by González-Romá, Peiró, and Tordera (2002) was used to examine the moderating effect of price consciousness on the relationship between clothing interest and purchase intention. First, a cluster analysis was conducted to profile the segments according to the level of price consciousness in the data. This was done by segregating the respondents into two groups based on the median value (centroid) of price consciousness. The cluster solution gave rise to two levels: (1) high-price consciousness (the group of respondents with a mean rating higher than the centroid), and (2) low-price consciousness (the group of respondents with a mean rating lower than the centroid). The second step involved a hierarchical regression approach to determine the moderation effect. A moderation effect is deemed to exist if the interaction term gives a significant contribution over and above that of the main-effect model. In other words, moderation exists if the inclusion of the interaction term in the model yields a significant increase in $\mathrm{R}^{2}$.

As indicated in Table 5, the results of the hierarchical regression analysis indicated that price consciousness moderated the relationship between clothing interest and purchase intention. The addition of the interaction term (step 3) yielded a significant contribution over and above that of the main effect model, which was shown in step $1 . \mathrm{R}^{2}$ increased from 0.237 to $0.634\left(\Delta \mathrm{R}^{2}=0.397, \mathrm{p}<0.01\right)$ upon inclusion of the interaction term (purchase intention $\mathrm{x}$ price consciousness).

\section{Display Table 5 here.}

The interaction effect of price consciousness was plotted in a graph as shown in Figure 2. The graph in Figure 2 indicated that the slope of the low price conscious group was steeper than that of the high price conscious group. This means that clothing interest is more strongly associated with purchase intention for the low price conscious group as compared to the high price conscious group. Hence, $\mathrm{H} 7$ was also supported by the data. 


\section{Display Figure 2 here.}

\section{Discussion and Conclusion}

Several points are worth noting based on the findings from the study. Firstly, need for uniqueness and self-concept were found to have a significant positive influence on clothing interest among the consumers of Generation $\mathrm{Y}$ in Malaysia. The findings are consistent with prior studies (e.g. Kumar et al. 2009; Tuncay and Otnes 2008). Hence, it is revealed that individuals of Generation $\mathrm{Y}$ have their very own personal characteristics and identity in selecting clothing products. They wish to differentiate themselves from others in the society with a unique fashion sense. Generation Y consumers are easily grasp onto new concepts, image-driven, emphasized on fashion uniqueness and value, prefer colorful fabric, etc., apparel manufacturers need to produce unique styles for their products by collaborating with creative fashion designers. They may promote a new fashion concept that are stylish, colorful, have variety of fabrics, athletic feel, combining elements of casual, practical like cargo pants, combining the effect of technologies, and trendy design in the market to create positive clothing interest among the Generation Y consumers. This is because a fashion sense that fits the profile of Generation Y would generate purchase intention and create demand for clothing products of a certain brand.

Brand image and WOM are significant predictors of clothing interest of the Malaysian consumers that fall in the category of generation $\mathrm{Y}$. the findings in the present study is aligned with the evidence from the past literatures (e.g. McKinney 2004; Zeb et al. 2011). A favorable image of the clothing in the consumers' mind would develop their interests and intention to buy. Brand image provides consumers with an overall perception of the product and it somehow influences them cognitively. Clothing manufacturers need to adopt an effective advertising strategy to communicate and to instill a positive image in the mind of the consumers. They may use media ads, promotion campaigns, spokesperson, and sponsorship to change consumers' perception towards their products. However, WOM could be more effective in arousing someone's interest and intention in purchasing apparel products. Positive WOM through friends, peers, family members, and social networks is a powerful mechanism to attract people to a certain product. To utilize WOM, clothing producers and retailers must be able to deliver their brand promises by providing outstanding customer service, collecting feedback and testimonials, and offering the desired level of 
product quality. The results of this study did show that perceived quality of clothing has a positive relationship with individuals' clothing interest. The quality of clothing may be enhanced by the usage of relatively quality materials, quality stiches, and good workmanship (Tsiotsou, 2006). For example, the importance of quality has always been the focus of Levi's, a reputable apparel company from the United States. Levi's believes that quality products will be able to sustain the company (levistrauss.com, 2015).

Although consumers' clothing interest is positively related to their purchase intention (Son et al. 2013; Vikkraman and Sumathi 2012), this relationship is moderated by the level of price consciousness. In other words, price-conscious consumers of Generation Y may not intend to buy a certain brand of clothing even though they have a strong interest in the clothing. Hence, the clothing retailers are advised to pay attention on the way they price their products as this could influence consumers' purchase intention. Various pricing strategies such as odd pricing, reference pricing, price bundling, quantity discount, cash discount, priceoff promotion, coupons, rebates, and reward system may be used to entice price-conscious consumers.

As a conclusion, there is no doubt that the fashion industry is growing in a dynamic environment. Identifying factors that influence clothing interest and buying intention would have been a great advantage for the apparel manufacturers and retailers. In view of the competitive landscape of the garment and retail industry, it is vital for the manufacturers, retailers, marketers and other relevant parties to be more diligent in attracting and stay relevant to the needs and wants of the potential customers. Understanding what arouse customers' interest in clothing would be useful for them to accurately segment their target market, develop effective promotion strategies, and create loyalty among the customers. The findings of this study are especially important due to the growing influx of international apparel brands in Malaysian economy. 


\section{References}

Aaker, D. A. 2009. Managing brand equity. New York: The Free Press

Alfonso, V. C., Allison, D. B., Rader, D. E., and Gorman, B. S. 1996. "The extended satisfaction with life scale: Development and psychometric properties." Social Indicators Research 38(3): 275-301.

Alford, B. L., and Biswas, A. 2002. "The effects of discount level, price consciousness and sale proneness on consumers' price perception and behavioral intention." Journal of Business Research 55(9): 775-783.

Arndt, J. 1967. "Role of product-related conversations in the diffusion of a new product." Journal of Marketing Research 4(3): 291-295.

Banister, E. N., and Hogg, M. K. 2004. "Negative symbolic consumption and consumers' drive for self-esteem: The case of the fashion industry." European Journal of Marketing 38(7): 850-868.

Bao, Y., and Shao, A. T. 2002. "Nonconformity advertising to teens." Journal of Advertising Research 42(3): 56-65.

Bye, E., and McKinney, E. 2007. "Sizing up the wardrobe-Why we keep clothes that do not fit." Fashion Theory 11(4): 483-498.

Chang, S. J., Van Witteloostuijn, A., and Eden, L. (2010). "From the editors: Common method variance in international business research." Journal of International Business Studies 41(2): 178-184.

Chen, I. J., Gupta, A., and Rom, W. 1994. "A study of price and quality in service operations." International Journal of Service Industry Management 5(2): 23-33.

Choi, S. and Kim, M. 2007. "The effectiveness of "scratch and save" promotions: the moderating roles of price consciousness and expected savings." Journal of Product \& Brand Management 16(7): 469-480.

Companies and Markets. 2015. Apparel Industry Trends 2015. Retrieved from: http://www.free2work.org/trends/apparel2015/Free2Work-Apparel-Industry-Trends2015.pdf

Cook, S. 2010. Customer care excellence: How to create an effective customer focus. London: Kogan Page Publishers.

Dictionary.com. 2014. Meaning of Unique. Retrieved from: http://dictionary.reference.com/browse/ unique?s=t

Dodds, W. B., Monroe, K. B., and Grewal, D. 1991. "Effects of price, brand, and store information on buyers' product evaluations." Journal of Marketing Research 28(3), 307-319.

Euromonitor International. 2013. Retailing in Malaysia. Available at: http://www.euromonitor.com/retailing-in-malaysia/report

Farber, B. A. 1983. Stress and burnout in the human service professions. New York: Pergamon Press.

Fornell, C., and Larcker, D. F. 1981. "Structural equation models with unobservable variables and measurement error: Algebra and statistics." Journal of Marketing Research 18(3): 382-388. 
Gauzente, C., and Roy, Y. 2012. "Message content in keyword campaigns, click behavior, and price-consciousness: A study of millennial consumers." Journal of Retailing and Consumer Services 19(1): 78-87.

González-Romá, V., Peiró, J. M., and Tordera, N. 2002. An examination of the antecedents and moderator influences of climate strength. Journal of Applied Psychology 87(3): 465.

Gurel, L. M. 1974. "Dimensions of Clothing Interest Based On Factor Analysis of Creekmore's 1968 Clothing Measure.” Unpublished Doctoral Dissertation, University Of North Carolina: USA.

Hair, J. F. J., Black, W. C., Babin, B. J., Anderson, R. E., and Tatham, R. L. 2010. Multivariate data analysis a global perspective. Upper Saddle River, NJ: Pearson Education International.

Han, H., and Ryu, K. 2009. "The roles of the physical environment, price perception, and customer satisfaction in determining customer loyalty in the restaurant industry." Journal of Hospitality \& Tourism Research 33(4): 487-510.

Harrison-Walker, L. J. 2001. "The measurement of word-of-mouth communication and an investigation of service quality and customer commitment as potential antecedents." Journal of Service Research 4(1): 60-75.

Hsieh, A. T., and Li, C. K. 2008. "The moderating effect of brand image on public relations perception and customer loyalty." Marketing Intelligence \& Planning 26(1): 26-42.

Hung, K. H., and Li, S. Y. 2007. "The influence of eWOM on virtual consumer communities: Social capital, consumer learning, and behavioral outcomes." Journal of Advertising Research 47(4): 485-495.

Jayasingh, S., and Eze, U. C. 2012. "Analyzing the intention to use mobile coupon and the moderating effects of price consciousness and gender." International Journal of EBusiness Research 8(1): 54-75.

Kaiser, S. 1997. The social psychology of clothing (2 $2^{\text {nd }}$ edition). New York: Fairchild Publications.

Kamenidou, I., Mylonakis, J., and Nikolouli, K. 2007. "An exploratory study on the reasons for purchasing imported high fashion apparels: The case of Greece." Journal of Fashion Marketing and Management: An International Journal 11(1): 148-160.

Kawabata, H., and Rabolt, N. J. 1999. Comparison of clothing purchase behaviour between US and Japanese female university students. Journal of Consumer Studies and Home Economics 23(4): 213-223.

Keller, K. L. 1993. "Conceptualizing, measuring, and managing customer-based brand equity." Journal of Marketing 57(1): 1-22.

Kiecker, P., and Cowles, D. 2002. "Interpersonal communication and personal influence on the Internet: A framework for examining online word-of-mouth." Journal of Euromarketing 11(2): 71-88.

Kim, E. Y., Knight, D., and Pelton, L. 2009. "Modeling brand equity of a US apparel brand as perceived by Generation Y consumers in the emerging Korean market." Clothing and Textiles Research Journal 27(4): 247-258. 
Khan, N., Hui, L. H., Chen, T. B., and Hoe, H. Y. 2016. "Impulse Buying Behaviour of Generation Y in Fashion Retail." International Journal of Business and Management 11(1): 144.

Koh, T. H., and Fang, W. C. 2012. "The effects of corporate social responsibility on purchase intention: The mediating effects of brand attachment and brand image." Journal of Business Administration 94: 41-68.

Kukar-Kinney, M., Xia, L., and Monroe, K. B. 2007. "Consumers' perceptions of the fairness of price-matching refund policies." Journal of Retailing, 83(3): 325-337.

Kumar, A., Kim, Y. K., \& Pelton, L. 2009. "Indian consumers' purchase behavior toward US versus local brands." International Journal of Retail and Distribution Management 37(6): 510-526.

Lee, M. and Burns, L. D. 1993. "Self consciousness and clothing purchase criteria of Korean and United States college women." Clothing and Textiles Research Journal 11(4): 3240.

levistrauss.com. 2015. Our Story. Retrieved from: http://www.levistrauss.com/ourstory/\#heritage-timeline

Lichtenstein, D. R., Ridgway, N. M., and Netemeyer, R. G. 1993. "Price perceptions and consumer shopping behavior: a field study." Journal of Marketing Research 30(2): 234-245.

Lukavsky, J., Butler, S., and Harden, A. J. 1995. "Perceptions of an instructor: Dress and students' characteristics." Perceptual and Motor Skills 81(1): 231-240.

Lumpkin, J. 1985. "Shopping orientation segmentation of the elderly consumer." Journal of the Academy of Marketing Science 13(1-2): 271-289.

Lynn, M., and Harris, J. 1997. "The desire for unique consumer products: A new individual differences scale." Psychology and Marketing 14(6): 601-616.

Martin, O., and Jacob, F. 2010. "Empowered involvement and word of mouth: conceptual model and first empirical evidence." Journal of Marketing Trends 1: 25-33.

Malhotra, N.K. 2009. Marketing Research: An Applied Orientation (6 ${ }^{\mathrm{h}}$ Edition). New Jersey, USA: Prentice Hall

Maslow, A.H. 1987. Motivation and personality (3rd Edition). New York, USA: Harper \& Row.

Matthiesen, I., and Phau, I. 2010. "Brand image inconsistencies of luxury fashion brands: A buyer-seller exchange situation model of Hugo Boss Australia." Journal of Fashion Marketing and Management: An International Journal 14(2): 202-218.

Malhotra, N.K., Kim, S.S., and Patil, A. 2006. "Common method variance in IS research: A comparison of alternative approaches and a reanalysis of past research." Management Science 52(12): 1865-1883.

McKinney, L. N., Legette-Traylor, D., Kincade, D. H., and Holloman, L. O. 2004. "Selected social factors and the clothing buying behaviour patterns of black college consumers." The International Review of Retail, Distribution and Consumer Research 14(4): 389-406.

Nielsen. 2009. Nielsen online provides fastest growing social networks for September 2008. Available at: http://www.nielsen-online.com/ 
O'Cass, A., and Grace, D. 2004. "Exploring consumer experiences with a service brand." Journal of Product and Brand Management 13(4): 257-268.

Palazón, M., and Delgado, E. 2009. "The moderating role of price consciousness on the effectiveness of price discounts and premium promotions." Journal of Product and Brand Management 18(4): 306-312.

Paul, P. 2001. "Getting inside gen Y.” American Demographics 23(9): 42-49.

Phau, I., and Lau, K. C. 2001. "Brand personality and consumer self-expression: Single or dual carriageway?." Brand Management 8(6): 428-444.

Piacentini, M., and Mailer, G. 2004. "Symbolic consumption in teenagers' clothing choices." Journal of Consumer Behaviour 3(3): 251-262.

Promar International. 2001. Generation Y: Winning Snack Strategies. Available at: http://www.promarinternational.com/pdfs/IndustryStrategicStudies/ConsumerIns ights/Gen\%20Y\%20snacks\%20management\%20summary.pdf

Rajagopal. 2006. "Insights from research Brand excellence: Measuring the impact of advertising and brand personality on buying decisions." Measuring Business Excellence 10(3): 56-65.

Rosenfeld, L. B., and Plax, T. G. 1977. "Clothing as communication." Journal of Communication 27(2): 24-31.

Ruban, M. 2002. Quality Control in Road Construction. Holland: CRC Press.

Ryu, K., and Han, H. 2010. "Influence of the quality of food, service, and physical environment on customer satisfaction and behavioral intention in quick-casual restaurants: Moderating role of perceived price." Journal of Hospitality and Tourism Research 34(3): 310-329.

Saunders, M., Lewis, P., and Thornhill, A. 2012. Research Methods for Business Students (6th Edition). Harlow, England: Pearson.

Schindler, R., and Bickart, B. 2012. "Perceived helpfulness of online consumer reviews: the role of message content and style." Journal of Consumer Behaviour 11(3): 234-243.

Sekaran, U. 2005. Research Methods for Business ( $4^{\text {th }}$ edition). Singapore: John Wiley and Sons.

Stanforth, N. 2009. "Fashion merchandising internships for the millennial generation." International Journal of Fashion Design, Technology and Education 2(2): 91- 99.

Son, J., Jin, B., and George, B. 2013. "Consumers' purchase intention toward foreign brand goods." Management Decision 51(2): 434-450.

Stryker, S. 1987. Identity theory: Development and extensions, in Self and identity: Psychosocial perspectives, Chichester: John Wiley and Sons Ltd.

Subhani, M. I., Hasan, S. A., and Osman, A. 2011. "New Article of Clothing translates the Mood of an Individual." International Journal of Business and Social Science 2(23): 183- 185.

Snyder, C., and Fromkin, H. 1980. Uniqueness: The human pursuit of difference. New York: Plenum.

Tian, K. T., Bearden, W., and Hunter, G. 2001. "Consumers' need for uniqueness: Scale development and validation." Journal of Consumer Research 28(2): 50-66.

Tian, K. T., and McKenzie, K. 2001. "The long-term predictive validity of consumers' need for uniqueness." Journal of Consumer Psychology 10(3): 1971-1973. 
Tee, P. K., Gharleghi, B., and Chan, B. Y. F. 2013. "Malaysian young consumer preferences in choosing international fashion brand." Journal of Human and Social Science Research 1(1): 31-38.

Trusov, M., Bucklin, R. E., and Pauwels, K. 2009. "Effects of word-of-mouth versus traditional marketing: findings from an internet social networking site." Journal of Marketing 73(5): 90-102.

Tsiotsou, R. 2006. "The role of perceived product quality and overall satisfaction on purchase intentions." International Journal of Consumer Studies 30(2): 207-217.

Tuncay, L., and Otnes, C. 2008. "The use of persuasion management strategies by identityvulnerable consumers: The case of urban heterosexual male shoppers." Journal of Retailing 84(4): 487-499.

Vikkraman, P., and Sumathi, N. 2012. "Purchase Behaviour in Indian Apparel Market: An Analysis." ZENITH International Journal of Business Economics and Management Research 2(2): 1-12.

Watchravesringkan, K., Yan, R. N., and Yurchisin, J. 2008. "Cross-cultural invariance of consumers' price perception measures: Eastern Asian perspective." International Journal of Retail and Distribution Management 36(10): 759-779.

Workman, J., and Kidd, L. 2000. "Use of the need for uniqueness scale to characterize fashion consumer groups.” Clothing and Textiles Research Journal 18(4): 227-236.

Zeb, H., Rashid, K., and Javeed, B. 2011. "Influence of Brands on Female Consumer's Buying Behavior in Pakistan." International Journal of Trade, Economics and Finance 2(3): 225-231.

Zeithaml, V. A. 1988. "Consumer perception of price, quality, and value: A means-end model and synthesis of evidence." Journal of Marketing 52(July): 2-22. 
Table 1. Respondents' Demographic Profile

\begin{tabular}{|c|c|c|c|}
\hline Variable & Classification & Frequency & Percentage $(\%)$ \\
\hline \multirow[t]{2}{*}{ Gender } & Male & 132 & 45.2 \\
\hline & Female & 160 & 54.8 \\
\hline \multirow{2}{*}{ Marital } & Single & 188 & 64.4 \\
\hline & Married & 104 & 35.6 \\
\hline \multirow{6}{*}{$\begin{array}{l}\text { Educational } \\
\text { Level }\end{array}$} & Primary School & 11 & 3.8 \\
\hline & Secondary School & 33 & 11.3 \\
\hline & Diploma/Higher Diploma & 72 & 24.7 \\
\hline & Bachelor's Degree & 130 & 44.5 \\
\hline & Master's Degree & 41 & 14.0 \\
\hline & PhD & 5 & 1.7 \\
\hline \multirow{3}{*}{ Employment } & Unemployed & 25 & 8.6 \\
\hline & Full time worker & 175 & 59.9 \\
\hline & Part time worker/ Freelancer & 92 & 31.5 \\
\hline \multirow[t]{5}{*}{ Income } & Less than RM 3,000 & 78 & 26.7 \\
\hline & RM 3,001 - RM 6,000 & 139 & 47.6 \\
\hline & RM 6,001 - RM 9,000 & 37 & 12.7 \\
\hline & More than RM 9,001 & 24 & 8.2 \\
\hline & Confidential & 14 & 4.8 \\
\hline \multirow{4}{*}{$\begin{array}{l}\text { Number of } \\
\text { Shopping for } \\
\text { clothes per } \\
\text { month }\end{array}$} & $1-3$ times & 124 & 42.5 \\
\hline & $4-6$ times & 99 & 33.9 \\
\hline & $7-9$ times & 41 & 14.0 \\
\hline & more than 10 times & 28 & 9.6 \\
\hline
\end{tabular}

Table 2. Convergent Validity for the Variables

\begin{tabular}{lcccc}
\hline Variables & Items & F.L & AVE $(>0.50)$ & CR $(>0.70)$ \\
\hline Brand Image & 3 & $0.701-0.833$ & $\mathbf{0 . 6 5 2}$ & $\mathbf{0 . 8 8 4}$ \\
\hline Word of Mouth & 5 & $0.712-0.835$ & $\mathbf{0 . 6 4 3}$ & $\mathbf{0 . 8 6 2}$ \\
\hline Self-concept & 5 & $0.634-0.842$ & $\mathbf{0 . 5 7 6}$ & $\mathbf{0 . 8 6 4}$ \\
\hline Perceived Quality & 3 & $0.682-0.894$ & $\mathbf{0 . 6 0 2}$ & $\mathbf{0 . 8 7 2}$ \\
\hline Need for Uniqueness & 5 & $0.627-0.933$ & $\mathbf{0 . 5 8 1}$ & $\mathbf{0 . 8 6 7}$ \\
\hline Clothing Interest & 3 & $0.684-0.882$ & $\mathbf{0 . 6 1 3}$ & $\mathbf{0 . 8 6 9}$ \\
\hline Price Consciousness & 6 & $0.692-0.853$ & $\mathbf{0 . 5 9 7}$ & $\mathbf{0 . 8 4 3}$ \\
\hline Purchase Intention & 3 & $0.695-0.824$ & $\mathbf{0 . 6 8 5}$ & $\mathbf{0 . 9 1 1}$ \\
\hline
\end{tabular}

Note: $\mathrm{F} . \mathrm{L}=$ factor loadings, $\mathrm{AVE}=$ average variance extracted, $\mathrm{CR}=$ composite reliability 
Table 3. Discriminant Validity for the Measurement Model

\begin{tabular}{lccccccccc}
\hline & AVE & $\mathbf{1}$ & $\mathbf{2}$ & $\mathbf{3}$ & $\mathbf{4}$ & $\mathbf{5}$ & $\mathbf{6}$ & $\mathbf{7}$ & $\mathbf{8}$ \\
\hline Brand Image & $\mathbf{0 . 6 5 2}$ & $\mathbf{0 . 8 0 7 ^ { \boldsymbol { a } }}$ & & & & & & & \\
Word of Mouth & $\mathbf{0 . 6 4 3}$ & $0.490^{\boldsymbol{b}}$ & $\mathbf{0 . 8 0 1}$ & & & & & & \\
Self-concept & $\mathbf{0 . 5 7 6}$ & 0.247 & 0.024 & $\mathbf{0 . 7 8 9}$ & & & & & \\
Perceived Quality & $\mathbf{0 . 6 0 2}$ & 0.436 & 0.433 & 0.087 & $\mathbf{0 . 7 7 6}$ & & & & \\
Need for Uniqueness & $\mathbf{0 . 5 4 1}$ & 0.423 & 0.389 & 0.091 & 0.081 & $\mathbf{0 . 7 3 6}$ & & & \\
Clothing Interest & $\mathbf{0 . 6 1 3}$ & 0.455 & 0.217 & 0.171 & 0.188 & 0.232 & $\mathbf{0 . 7 8 3}$ & & \\
Price Consciousness & $\mathbf{0 . 5 9 7}$ & 0.324 & 0.254 & 0.183 & 0.171 & 0.297 & 0.312 & $\mathbf{0 . 7 7 3}$ & \\
Purchase Intention & $\mathbf{0 . 6 8 5}$ & 0.241 & 0.300 & 0.192 & 0.157 & 0.651 & 0.212 & 0.189 & $\mathbf{0 . 8 2 3}$ \\
\hline
\end{tabular}

Notes: $A V E=$ average variance extracted, ${ }^{\mathrm{a}}$ The diagonal entries (in bold and italics) represent the squared root average variance extracted by the construct, ${ }^{b}$ The off-diagonal entries represent the variance shared between constructs.

Table 4. Results of the Path Analysis

\begin{tabular}{lccc}
\hline & S.E & C.R & P Value \\
\hline H1: Need for Uniqueness $\rightarrow$ Clothing Interest & 0.243 & 3.547 & 0.000 \\
H2: Self-Concept $\rightarrow$ Clothing Interest & 0.264 & 2.887 & 0.004 \\
H3: Brand Image $\rightarrow$ Clothing Interest & 0.382 & 5.345 & 0.000 \\
H4: Word of Mouth $\rightarrow$ Clothing Interest & 0.352 & 6.101 & 0.000 \\
H5: Perceived Quality $\rightarrow$ Clothing Interest & 0.212 & 2.781 & 0.005 \\
H6: Clothing Interest $\rightarrow$ Purchase Intention & 0.455 & 3.155 & 0.000 \\
\hline
\end{tabular}

Notes: S.E $=$ Standardized Estimate, $\mathrm{C} . \mathrm{R}=$ Critical Ratio

Table 5. Moderating Effect of Price Consciousness

\begin{tabular}{lccc}
\hline Dependent Variables & Step 1 & Step 2 & Step 3 \\
\hline Purchase Intention & $0.486^{* *}$ & $0.512^{* *}$ & $0.651^{* *}$ \\
Price Consciousness & & $0.279 * *$ & $0.240^{*}$ \\
Interaction (purchase intention $\mathrm{x}$ & & & $0.191 * *$ \\
price consciousness) & 0.237 & 0.602 & 0.634 \\
$\mathrm{R}^{2}$ & & 0.365 & 0.032 \\
$\Delta \mathrm{R}^{2}$ & & \\
Notes: Independent Variable= Clothing & Interest, **Significant & at $99 \%$ \\
level, ${ }^{*}$ Significant at 95\% level. &
\end{tabular}




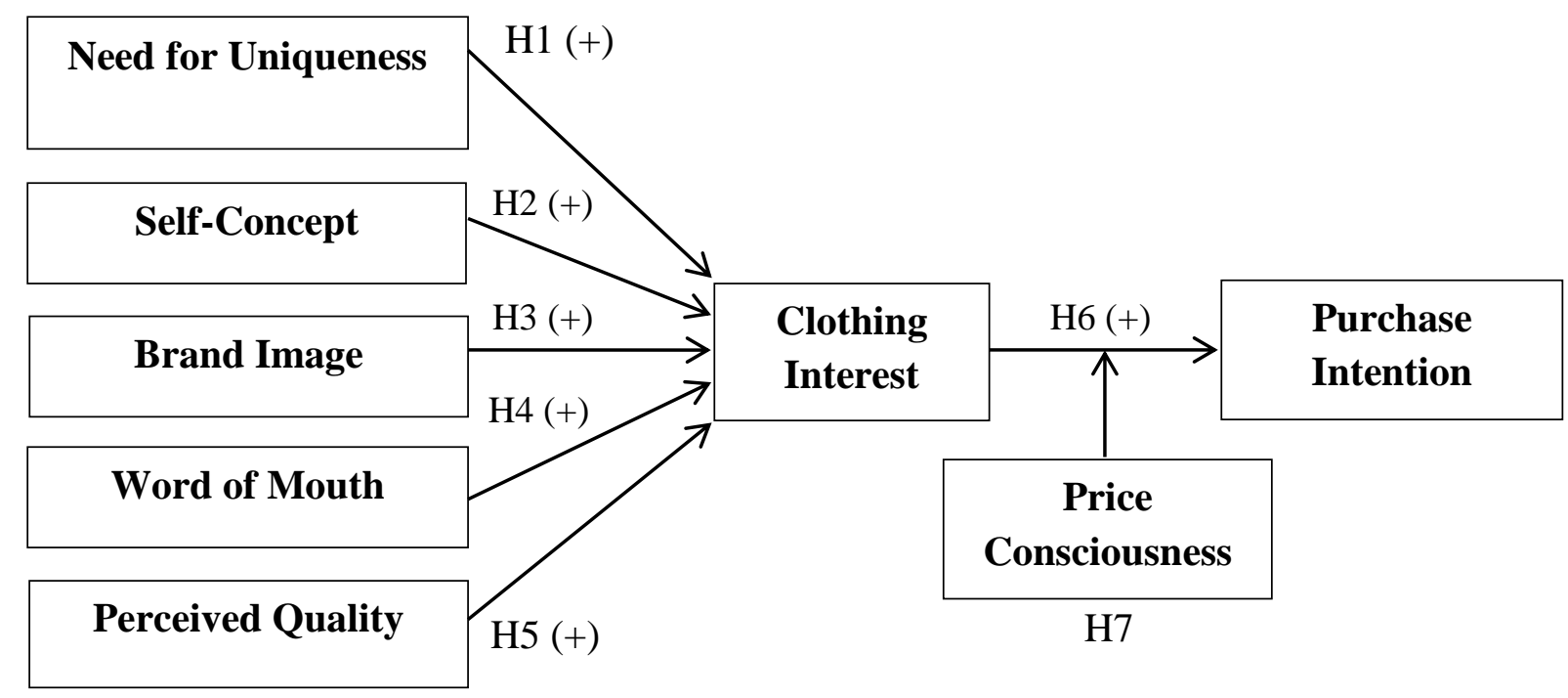

Figure 1. Research Model

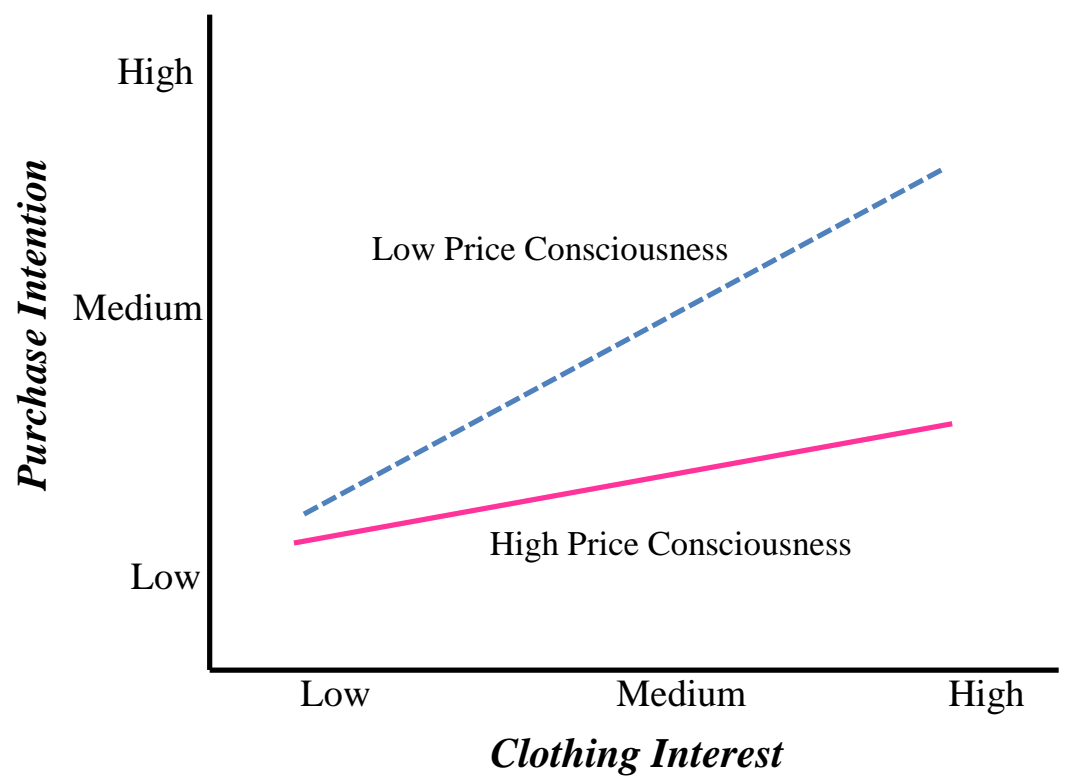

Figure 2. The Moderation Effect of Price Conciousness on the Relationship between Clothing Interest and Purchase Intention

\section{Note:}

This article has been published in The International Review of Retail, Distribution and Consumer Research (Taylor \& Francis). 